University of Nebraska - Lincoln

DigitalCommons@University of Nebraska - Lincoln

USDA National Wildlife Research Center - Staff

Publications

U.S. Department of Agriculture: Animal and Plant Health Inspection Service

$1-1-2005$

Potential consequences of the coqui frog invasion in Hawaii

\author{
Karen H. Beard \\ Utah State University, karen.beard@usu.edu \\ William C. Pitt \\ Utah State University
}

Follow this and additional works at: https://digitalcommons.unl.edu/icwdm_usdanwrc

Part of the Environmental Sciences Commons

Beard, Karen H. and Pitt, William C., "Potential consequences of the coqui frog invasion in Hawaii" (2005). USDA National Wildlife Research Center - Staff Publications. 52.

https://digitalcommons.unl.edu/icwdm_usdanwrc/52

This Article is brought to you for free and open access by the U.S. Department of Agriculture: Animal and Plant Health Inspection Service at DigitalCommons@University of Nebraska - Lincoln. It has been accepted for inclusion in USDA National Wildlife Research Center - Staff Publications by an authorized administrator of DigitalCommons@University of Nebraska - Lincoln. 


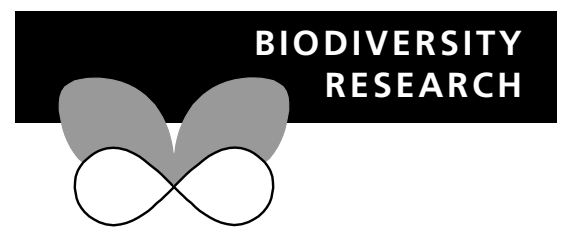

\title{
Potential consequences of the coqui frog invasion in Hawaii
}

\author{
Karen H. Beard ${ }^{1, \star}$ and William C. Pitt ${ }^{2}$
}

${ }^{1}$ Forest, Range and Wildlife Sciences Department and Ecology Center, Utah State University, Logan, UT 84322-5230, USA, and ${ }^{2}$ USDA/ APHIS/WS/National Wildlife Research Center, Hilo Field Station, Hilo, HI 96721, USA

${ }^{*}$ Correspondence: Karen H. Beard, Forest, Range and Wildlife Sciences Department and Ecology Center, Utah State University, Logan, UT 84322-5230, USA.

E-mail: kbeard@cc.usu.edu

\begin{abstract}
The Puerto Rican frog, Eleutherodactylus coqui, has invaded Hawaii and has negatively impacted the state's multimillion dollar floriculture, nursery and tourist industries; however, little is known about the ecological consequences of the invasion. Using data from Puerto Rico and Hawaii, the authors summarize the potential consequences of the invasion and describe future research needs. It could be predicted that the coqui would reduce the abundance of Hawaii's endemic invertebrates. However, data suggest that coquis are mostly consuming non-native invertebrates, and not invertebrate pests, such as mosquitoes and termites. Endemic invertebrates are likely to represent a portion of the coqui diet, but it remains uncertain which endemic invertebrates are most threatened by coqui predation and whether there will be indirect effects that benefit or harm them. It could be predicted that coquis would compete with endemic birds for invertebrate prey, but there is presently little overlap in the habitats used by coquis and endemic birds. Although, coquis may make bird re-invasion into lowland ecosystems more difficult; alternatively, coquis could serve as an additional food source for some endemic birds. Finally, it could be predicted that coquis serve as a food source for endemic-bird predators, such as rats and mongoose, and bolster their abundance. Preliminary data suggest that coquis will not bolster rat or mongoose populations. Managing coqui populations in Hawaii has been a challenge. A population has not yet been eradicated using citric acid, the only federally approved pesticide for coquis. It is unlikely that coquis will ever be eradicated from the islands of Hawaii and Maui, where there are now hundreds of populations. Quick and severe responses to new introductions may be the only effective means of containing the spread of the coqui.
\end{abstract}

\section{Keywords}

Arthropods, biological invasions, Eleutherodactylus coqui, Hawaiian Islands, introduced mammals, native birds.

\section{INTRODUCTION}

A frog native to Puerto Rico, Eleutherodactylus coqui (hereafter referred to as the coqui) was introduced into Hawaii in the late 1980s (around 1988) via nursery plants from Florida or the Caribbean (Kraus et al., 1999). It was not until 10 years later that the coqui was recognized as a potentially problematic invader. In the first report of the invasion, 21 populations, mostly in and around nurseries, were identified (Kraus et al., 1998). By 2001, there were over 200 wild populations on the Big Island of Hawaii, 50 on Maui, one on Oahu, and one on Kauai (Kraus \& Campbell, 2002). The coqui is thought to have spread among islands via nursery plants, although the coqui has also been introduced intentionally by citizens who support the frog's presence in Hawaii. The number and size of coqui populations continues to increase with new populations being reported weekly (R. Sugihara, unpubl. data).
Because of the delayed response to their introduction and the continued expansion of their range on the Islands of Hawaii and Maui, there exists much doubt that the coqui will ever be eliminated from Hawaii. The coqui invasion is of economic concern to the State of Hawaii because it threatens multimillion dollar floriculture and nursery industries because of quarantine restrictions and de-infestation measures that are now required on plants to be exported (Kraus \& Campbell, 2002). The coqui also threatens private property value and tourism because of its loud (80-90 dBA at $0.5 \mathrm{~m}$ ) mating calls, which exceed levels set to minimize interference with the enjoyment of life (70 dBA, Department of Health, Hawaii Revised Statutes Section 324F-1). The coqui is thought to be an ecological threat to the State of Hawaii because they are able to attain some of the highest densities ever observed for terrestrial amphibian populations (roughly 20,570 individuals ha ${ }^{-1}$ on average in Puerto Rico) (Stewart \& Woolbright, 1996). 
In April 2004, the Mayor of Hilo declared the coqui situation a state of emergency because

'the threat that excessive noise emitted by the coqui frogs poses to human health and welfare, the unknown impact of the coqui frogs on the Island of Hawaii ecosystems, as well as its threat to the economic welfare of the Island of Hawaii'

As suggested in this statement, up to now little effort has been made to study the frog in a way that will reveal its ecological impacts. Rather, research on the coqui has appropriately focused on eradication. However, the lack of data showing ecological consequences is now hindering appropriate authorities and funds to continue eradications. Thus, information on the ecological consequences of the invasion is greatly needed.

Furthermore, the range of the coqui is not only expanding in Hawaii, but it also appears to be expanding globally (Joglar, 1998). There are stable coqui populations in the Dominican Republic and US Virgin Islands (Kraus et al., 1999). The coqui, apparently travelling in nursery plants from Hawaii, has already reached another Pacific island, Guam, and mainland United States, California and Connecticut. While the species may not be able to establish in cold or dry areas, it is likely to establish in other Carribbean and Pacific islands. Thus, implications from the research conducted on the ecological consequences of the coqui invasion in Hawaii are not restricted to Hawaii.

\section{THE HYPOTHESES}

The first paper describing the presence of the coqui in Hawaii presented three hypotheses describing potential ecological consequences: (1) coquis may reduce native arthropods; (2) coquis may compete with endemic birds, the majority of which are insectivorous; and (3) coquis may contribute to native bird declines by bolstering populations of bird predators (i.e. rats and mongoose) (Kraus et al., 1999). The coqui has already been the subject of a wide variety of studies in its native Puerto Rico, dealing with its ecology, behaviour and reproduction (e.g. Lavigne \& Drewry, 1970; Townsend \& Stewart, 1986; Woolbright \& Stewart, 1987; Stewart, 1995; Fogarty \& Vilella, 2002). While taking into account differences between Puerto Rican and Hawaiian forests, research from Puerto Rico should be able to inform the development of hypotheses about the ecological consequences of the coqui invasion in Hawaii. In this paper, we use data from Puerto Rico and Hawaii to describe the existing support for and the future research needed to address the three hypotheses proposed by Kraus et al. (1999).

\section{Reducing endemic arthropod prey}

Because the coqui is an abundant insectivore, the most obvious potential ecological consequence of the coqui invasion is a reduction in invertebrates. Research from Puerto Rico shows that coquis consume an estimated 114,000 invertebrates $\mathrm{ha}^{-1}$ night $^{-1}$ (Stewart \& Woolbright, 1996) and control population sizes of their prey (Beard et al., 2003a). Stomach analyses from Puerto Rico suggest that coquis mostly consume litter invertebrates
Table 1 Total number and percent of identifiable prey items found in 220 frog stomachs, 20 frogs from 11 sites in Hawaii (nine on the island of Hawaii and two on Maui $)^{*}$

\begin{tabular}{|c|c|c|c|}
\hline Scientific class $\dagger$ & Order & $\begin{array}{l}\text { Number of } \\
\text { prey items }\end{array}$ & $\begin{array}{l}\text { Percent of } \\
\text { total prey items }\end{array}$ \\
\hline \multicolumn{4}{|l|}{ Amphibia } \\
\hline & Anura & 1 & 0.1 \\
\hline \multicolumn{4}{|l|}{ Arachnida } \\
\hline & Acarina & 102 & 6.6 \\
\hline & Araneae & 30 & 1.9 \\
\hline Chilopoda & & 8 & 0.5 \\
\hline Diplopoda & & 15 & 1.0 \\
\hline Gastropoda & & 28 & 1.8 \\
\hline \multicolumn{4}{|l|}{ Insecta } \\
\hline & Blattodea & 2 & 0.1 \\
\hline & Coleoptera & 64 & 4.1 \\
\hline & Collembola & 127 & 8.2 \\
\hline & Dermaptera & 16 & 1.0 \\
\hline & Diptera & 48 & 3.1 \\
\hline & Hemiptera & 8 & 0.5 \\
\hline & Homoptera & 2 & 0.1 \\
\hline & Hymenoptera & 587 & 37.9 \\
\hline & Isoptera & 2 & 0.1 \\
\hline & Lepidoptera larvae & 11 & 0.7 \\
\hline & Unknown larvae & 5 & 0.3 \\
\hline \multicolumn{4}{|l|}{ Malacostraca } \\
\hline & Amphipoda & 351 & 22.6 \\
\hline & Isopoda & 116 & 7.5 \\
\hline \multicolumn{4}{|l|}{ Nematomorpha } \\
\hline & Oligochaeta & 1 & 0.1 \\
\hline \multicolumn{2}{|c|}{ Pseudoscorpionida } & 4 & 0.3 \\
\hline \multicolumn{2}{|l|}{ Unknown } & 21 & 1.4 \\
\hline \multicolumn{2}{|l|}{ Total } & 1550 & \\
\hline
\end{tabular}

${ }^{*}$ Sites on the Island of Hawaii include Akaka Falls State Park; Lava Tree State Park; Waipio Overlook; Manuka Natural Area Reserve; Kaumana Caves State Park; a forested plot near a refuse collection centre, Puna District; a forested plot near the Hilo airport; a Hawaiian Paradise Park residence; and a Kurtistown residence. Sites on Maui include Maliko Gulch; and a nursery in Kihei.

†Identifications are based on Borror et al. (1989).

(Stewart \& Woolbright, 1996), but research also shows that they control foliage and flying arthropod populations (Beard et al., 2003a). These effects could be devastating in Hawaii because invertebrates comprise the large majority of Hawaii's endemic fauna (Eldredge \& Miller, 1995).

To investigate what coquis are consuming in Hawaii, we collected coquis from nine sites on the Island of Hawaii and two sites on Maui in May and August 2004, respectively (Table 1). Locations within islands were selected for their diversity in foresttype, elevation and geological history, and because coqui populations in these locations were known to be in existence for at least 1 year. Twenty frog stomachs from each of the 11 sites $(66 \%$ male and $33 \%$ female) were collected, preserved in ethanol and their contents identified to either scientific order or family. Data from these individuals suggest that $38 \%$ of items consumed 
by coquis are ants (order Hymenoptera family Formicidae), entirely non-native species, and $23 \%$ of the items consumed are non-native amphipods (order Malacostraca family Amphipoda) (Table 1). Thus, it appears that coquis are mostly consuming non-native, leaf litter invertebrates.

It is not surprising that exotics constitute the majority of the coqui diet because coqui populations have mostly become established in nurseries, residential gardens, resort areas, state parks and lowland forests. These habitats are typically dominated by non-native plants and therefore non-native arthropods (Samways et al., 1996). Even the state parks and lowland forests that have been invaded by coquis are often dominated by non-native plants, such as strawberry guava (Psidium cattleianum) and albizia (Falcataria moluccana), although some are dominated by natives, such as ohia (Metrosideros polymorpha). To determine the native invertebrates most threatened by the invasion, future studies should determine the composition of native and exotic invertebrates in invaded communities. This is straightforward for some families and orders that are only represented by exotics (e.g. Formicidae, Isoptera), but will require identifying invertebrates to species for families and orders that are represented by both natives and exotics (e.g. Acarina, Coleoptera, Collembola and Diptera).

It has been suggested that the coqui may reduce important non-native invertebrate pests in Hawaii, such as mosquitoes, termites, and centipedes (Fullington, 2001; Singer, 2001). The potential reduction of mosquitoes is important because mosquitoes have contributed to native bird declines in Hawaii through avian malaria (van Riper \& van Riper, 1985). However, the coqui has not been observed to consume many mosquitoes in either Puerto Rico (Beard et al., 2003a) or in Hawaii (family Culicidae) (K. Beard, unpubl. data). We found no mosquitoes in coqui stomachs from Hawaii. In both Puerto Rico (Stewart \& Woolbright, 1996) and Hawaii (Table 1), termites (Isoptera) have been found to constitute a small percentage of the coqui diet. Other undesirable invertebrates, such as centipedes (Chilopoda), also constitute a small percentage of coqui stomach contents (Table 1). Stomach analyses have a known bias toward arthropods with robust body parts (Iverson et al., 2004). Because the reduction of invertebrates is likely to be one of the most important consequences of the invasion, future research should use complementary techniques to determine the effect of the invasion on invertebrates.

Another potential problem with stomach analyses is that these studies do not reveal the indirect effects of predation. For example, many of the invertebrates consumed by coquis consume other invertebrates, which could indirectly affect the abundance of other invertebrates, including endemics. In Puerto Rico, the coqui was shown to have indirect positive effects on litter invertebrates by increasing leaf-litter quality (Beard et al., 2003a). In addition, many of the arthropods that coquis consume play important roles in ecosystem processes, such as herbivory and decomposition of plant material. In Puerto Rico, herbivory rates were lower and leaf-litter decomposition rates were higher in the presence of coquis (Beard et al., 2003a). Coquis were also found to increase nutrient availability on the forest floor and plant growth rates by converting arthropods into more available nutrient forms in Puerto Rico (Beard et al., 2002).
If coquis have these fertilization effects in Hawaii, they could influence ecosystem properties and potentially alter floral and faunal species compositions. For example, it has long been known that fertilization effects can change plant species composition (Tilman, 1987; Hobbs \& Huenneke, 1992), and influence the colonization of new species, including invasives (Vitousek, 1986). This has especially been found to be the case in Hawaii, where native species show high tolerance of low resource environments compared to exotics (Goergen \& Daehler, 2001), and where studies have shown that exotic plants become more abundant in soils where nutrients are abundant (Ostertag \& Verville, 2002). Given the potential for fertilization effects to favour exotic plants and non-native invertebrates, the authors suggest that experiments be conducted to determine whether coquis are having important indirect effects on invertebrates communities, herbivory rates, and plant and microbe nutrient availability in Hawaii.

\section{Competition with endemic birds}

If coquis and endemic Hawaiian birds occupy the same habitat, they may compete for invertebrate prey items (Kraus et al., 1999). Because coquis have mostly invaded sites below $500 \mathrm{~m}$ (K. Beard, unpubl. data) while endemic Hawaiian birds are typically found above $500 \mathrm{~m}$, they do not appear to be competing at present. In Puerto Rico (Schwartz \& Hendersen, 1991) and Hawaii (Kraus \& Campbell, 2002), coquis are found from sea level to $1200 \mathrm{~m}$ in elevation (the top of the highest peak in Puerto Rico), and populations with the greatest densities occur below $500 \mathrm{~m}$ (Stewart \& Woolbright, 1996). While the coqui cannot survive on the highest peaks in Hawaii $(4200 \mathrm{~m}$ ) because of freezing temperatures, the elevational limit of the coqui in Hawaii remains uncertain. In Hawaii, there are habitats above $1200 \mathrm{~m}$, but the propagule pressure is presently low in these sites, so it is not clear if the coquis cannot establish at higher elevations or if they simply have not been introduced to higher elevations.

High elevation coqui invasions are of the greatest concern because the large majority of endemic birds are restricted to elevations above $500 \mathrm{~m}$, even though they originally occurred in the lowlands (Stattersfield et al., 1998). All but five endemic forest birds on the eight main islands are restricted to forests above $500 \mathrm{~m}$ (Ellis et al., 1992). In addition, it is often the island-wide endemics occurring below $500 \mathrm{~m}$ (i'iwi 300-2900 m, elepaio 300-3000 m, apapane 100-2900 m [more common above $1200 \mathrm{~m}$ ], common amakihi 100-3000 m, and anianiau 0-1550 m) that are least threatened (Stattersfield et al., 1998). A few notable exceptions include the Nihoa millerbird (Acrocephalus familiaris kingi) and Nihoa finch (Telespyza ultima), but coquis are less likely to establish on the northwestern Hawaiian Islands, because human activity is low in these areas. There are some recent data suggesting that at least some endemic birds might be developing resistance to avian malaria, which has been thought to be the primary cause of declines in the lowlands (Atkinson et al., 2000). If endemic birds do recover and move into lower elevation forests, or if coquis move into upland forests, there is a greater possibility that endemic birds and coquis will compete. 
The second major factor that could limit competition between coquis and endemic birds is that coquis are nocturnal and the majority of birds are diurnal. In Puerto Rico, there are two distinct food webs, one nocturnal and one diurnal. For example, there is only a $13 \%$ overlap of species in the diet of nocturnal coquis and diurnal Anolis lizards, even though they are both insectivorous and forage on similar types of prey (Reagan, 1996). Similarly, the prey base for coquis and endemic birds in Hawaii may be different. In terms of both foraging habits and elevational distributions, coquis appear most likely to compete with elepaio species (Chasiempis spp.), the i'iwi (Vestiaria coccinea) and thrushes (Myadestes spp.). Other endemic birds that share foraging habits with the coqui include the nene (Nesochen sandvicensis) and the Hawaiian duck (Anas wyvilliana), but these are typically found along forest edges, and therefore are less likely to overlap with coquis. Some birds that share foraging habits with the coqui are so rare that any effect on them could be significant, such as the po'o-uli (Melamprosops phaesoma).

The coqui appears more likely to compete with the only bat native to Hawaii, the endangered Hawaiian hoary bat (Lasiurus cinereus semotus). This bat can be found from coastal areas to over $1200 \mathrm{~m}$ on all major Hawaiian Islands. Bats are nocturnal and feed on a variety of insects including Coleoptera, Diptera, Hemiptera and Lepidoptera (Whitaker \& Tomich, 1983; Belwood \& Fullard, 1984). However, because bats feed primarily on flying insects, there appears to be a small chance of prey base overlap based on preliminary coqui diet analyses (Table 1). Nonetheless, because of the endangered status of the bat and the potential for the coqui to influence arthropod communities through indirect effects, potential interactions between these species warrants further investigation.

\section{Bolstering populations of bird predators}

Another hypothesis is that coquis serve as an additional food source for native-bird predators, bolstering their abundances and reducing endemic birds through apparent competition (Kraus et al., 1999). More specifically, coquis could bolster rat (three species, especially Rattus rattus) and mongoose (Herpestes javanicus) populations, which are known to be bird predators. It is of concern that if the brown tree snake (Boiga irregularis) were to establish in Hawaii, it would predate on endemic birds and sustain itself on coquis. It is likely that the brown tree snake would consume many coquis because it focuses on ectothermic prey when young (Savidge, 1988) and prey switches to abundant food sources (Rodda \& Fritts, 1992).

In Puerto Rico, the introduced rat ( $R$. rattus) and mongoose (H. javanicus) do not consume many coqui (Pimentel, 1955; Vilella, 1998). Rats are nocturnal yet they have been found to mostly consume vegetative material (Willig, 1996). Mongooses consume more vertebrates than rats do; however, they are diurnal and consume few coquis (Vilella, 1998). The only preliminary data to address this hypothesis were collected at Lava Tree State Park, Island of Hawaii, a location well known for its coqui infestation. The authors trapped mammals in June 2004 and removed their entire intestinal tract to identify digested items as vegetative, invertebrate, bird, amphibian or mammals. Of the 10 mongoose and 17 rat (R. rattus and Rattus exulans) stomachs investigated thus far, only one mongoose contained coquis (K. Beard, unpubl. data). Therefore, data from both ranges suggest that coquis are unlikely to bolster rat or mongoose populations.

Using mark-recapture data collected in Lava Tree State Park from five consecutive nights (methods described in Fogarty \& Vilella, 2001), the authors found that coqui densities can be twice as great as typical densities in Puerto Rico [estimated to be over 55,000 individuals ha ${ }^{-1}$ calculated using White \& Burnham (1999)]. There are many hypotheses to explain why some coqui populations might have such great densities in Hawaii. One proposed hypothesis is that coquis are experiencing 'enemy release' (Raloff, 2003). The most important documented predators of the coqui in its native range include invertebrates, such as amblypygids and crab spiders; birds, such as the screech owl (Otus nudipes), hawks, and a thrush (Turdus plumbeus); and native snakes (Stewart \& Woolbright, 1996). In their native habitat, coquis also compete with large predaceous invertebrates and Anolis lizards for prey (Reagan \& Waide, 1996). Many of these species and, more importantly, functional groups are virtually absent from the forests where coquis are invading. However, it is important to note that no research conducted in Puerto Rico has demonstrated that any species controls coqui population.

In addition, the possibility that insectivorous endemic birds or bats could consume coquis in Hawaii should be explored. In Puerto Rico, arthropod-preying birds, such as the pearly-eyed thrasher (Margarops fuscatus), the Puerto Rican woodpecker (Melanerpes portoricensis), the Puerto Rican tanager (Nesospingus speculiferus) and the red-legged thrush (Turdus plumbeus) are known to prey upon coqui (Stewart \& Woolbright, 1996), and for some vertebrate-preying birds, an amazingly high percentage of nestling diets consist of coqui (Waide, 1996). For example, up to $40 \%$ of nestling diets of screech owls (Snyder et al., 1987) and red-tailed hawks (Santana \& Temple, 1988) have been recorded to be coquis. Thus, it could be argued that coquis could serve as a food source to endemic birds in lowland areas, particularly birds like the Hawaiian owl (Asio flammeus sandwicensis). Furthermore, they are unlikely to be a limiting resource that native and exotic birds would compete for considering their high densities.

\section{MANAGEMENT OPTIONS}

Numerous control measures for coqui populations have been evaluated including hand-capturing, habitat modification, biological control, hot water treatments and chemical control, but none have been shown to be both effective and feasible for eradicating large populations covering large areas. Research from Puerto Rico does provide some potential mechanisms for reducing the coquis density and potential spread. For example, using information on their reproductive behavioural ecology from Puerto Rico, it was thought that control efforts focused on handcapturing calling males would both reduce fertilizations and doom existing clutches to failure (Townsend et al., 1984). However, because of their high densities and ability to migrate quickly over short distances (0-100 m, Gonser \& Woolbright, 1995), even persistent hand capturing has been found to be an ineffective 
method for complete frog removal (Beard, 2001). This method will only be effective at reducing populations in small, isolated areas.

Research on factors limiting coqui densities in Puerto Rico provides other potential mechanisms to reduce densities. It has been suggested that habitat structure for diurnal retreats and breeding limits population densities in Puerto Rico because the addition of both artificial and natural nest sites has been found to increase coqui density (Stewart \& Pough, 1983; Woolbright, 1991). Hence, removal of low-lying habitat structure, such as fallen woody debris, might be an effective management strategy for reducing densities in Hawaii. Similarly, studies on coqui habitat preferences in Puerto Rico suggests that coquis prefer Heliconia or banana plants, palms, ginger plants and other large-leafed species (Beard et al., 2003b). These non-native, largely ornamental species provide forage and breeding habitat for coquis wherever planted. Removing large-leaved, mostly non-native species and replacing them with small-leaved, native species should reduce coqui densities. For both these strategies, measures should be taken to ensure that removing coqui habitat does not negatively impact endemic invertebrate populations.

Research from Puerto Rico suggests that when there is abundant habitat near the forest floor (i.e. after hurricane events) and coqui population densities are not structurally limited, they are prey-limited (Beard, 2001). The same pattern may be found in Hawaii. In some locations on the Big island of Hawaii, such as Lava Tree State Park, the addition of artificial nests has not appeared to increase coqui densities or to be an appropriate tool for capturing coquis (W. Pitt, unpubl. data). At such sites, reducing prey could reduce coqui densities. This approach might work well in plant nurseries and other confined areas that are often dominated by non-native arthropods (K. Beard, unpubl. data). However, even within nurseries, the potential for reducing important arthropods should be considered.

Biological control including the introduction of predators, parasites and diseases has been considered. Although a few predators and parasites could be effective at reducing frog populations, the negative ecological effects of introducing these species may outweigh their potential effects on frog populations. This approach would require considerable research to evaluate the safety of releasing the control organism. Disease organisms are considered an attractive option because Hawaii has no native amphibians. However, the likelihood of success is low, primarily because diseases are most effective when affecting small populations of species with low reproductive capacity (Daszak et al., 2003). Further, many of the diseases associated with amphibian declines infect frogs in the tadpole stage, a nonexistent stage in these frogs with direct development. Nonetheless, the lethality of chytrid fungus was tested on coqui frogs from Hawaii and found to have little effect on frog survival (C. Carey, pers. comm.).

Hot water or vapour treatments are effective for killing frogs and their eggs; this method is especially effective in nursery settings (Chun et al., 2002). Hot $\left(>45^{\circ} \mathrm{C}\right.$ ) water or water vapour is applied to plants and pots for several minutes and can be followed by a cool rinse to minimize damage to plants. Orchids and bromeliads appear to be the most sensitive to these heat treatments and unfortunately are the primary species shipped.
Chemical control has been the most successful method to reduce frog populations. During the last 10 years, more than 50 chemicals have been evaluated for their effectiveness as frog toxicants (Campbell, 2002; Pitt \& Sin, 2004a). Although several have proved effective (i.e. caffeine and hydrated lime), only citric acid has been approved and labelled for use on coqui frogs. The only wild populations on Oahu and Kauai are thought to have been successfully contained using citric acid (S. Williamson and R. Sugihara, pers. comm.). In addition, research on the effects of citric-acid spraying on non-target species suggests that the longterm effect on invertebrate populations is not significant (Pitt \& Sin, 2004b). Citric acid also has minimal effects on nursery and wild plants (Pitt \& Sin, 2004c).

All vegetation is sprayed during an eradication effort, but the approach can miss frogs and protected eggs. Life history data from Puerto Rico would suggest that whether or not calling males are heard, two weeks after the initial spraying, spraying should be repeated to remove newly hatched juveniles (Townsend \& Stewart, 1985). Any adult coqui that survives these two sprayings will continue to breed. Puerto Rican data suggest that males can breed close to monthly while females can breed about once every 2 months year-round (Townsend \& Stewart, 1994). This suggests, at a minimum, that a third round of spraying should be conducted 2 weeks after the second spraying.

Although eradication efforts are underway, the success of this effort has been limited. To date there has been no official report of a successfully eradicated population. In general, eradication efforts have been limited to small, isolated areas and have not reduced the overall abundance or number of coqui populations. Most areas that have been sprayed with citric acid have not had consistent follow-up spraying. In addition, alternative approaches using citric acid, such as 'fogging' as opposed to spraying, have not been attempted even though they may be more effective at reaching hidden frogs. New control methods may need to be implemented or developed if eradication of the coqui frog from Hawaii is desired.

\section{ACKNOWLEDGEMENTS}

Support for this research came from the Jack Berryman Institute at Utah State University, the U.S. Fish and Wildlife Service, and the Hawaii Dept. of Land and Natural Resources. We thank N. Tuttle, D. Grant for help collecting preliminary data. We thank A. Kulmatiski, D. Townsend and an anonymous reviewer for commenting on earlier versions of this manuscript.

\section{REFERENCES}

Atkinson, C., Dusek, R., Woods, K. \& Iko, W. (2000) Pathogenicity of avian malaria in experimentally-infected Hawaii amakihi. Journal of Wildlife Diseases, 36, 197-204.

Beard, K.H. (2001) The ecological roles of a terrestrial frog, Eleutherodactylus coqui (Thomas), in the nutrient cycles of a subtropical wet forest in Puerto Rico. PhD Dissertation, Yale University, New Haven.

Beard, K.H., Vogt, K.A. \& Kulmatiski, A. (2002) Top-down effects of a terrestrial frog on nutrient dynamics. Oecologia, 133, 583-593. 
Beard, K.H., Eschtruth, A.K., Vogt, K.A., Vogt, D.J. \& Scatena, F.N. (2003a) The effects of the frog Eleutherodactylus coqui on invertebrates and ecosystem processes at two scales in the Luquillo Experimental Forest, Puerto Rico. Journal of Tropical Ecology, 19, 607-617.

Beard, K.H., McCullough, S. \& Eschtruth, A. (2003b) A quantitative assessment of habitat preferences for the Puerto Rican terrestrial frog, Eleutherodactylus coqui. Journal of Herpetology, $37,10-17$.

Belwood, J.J. \& Fullard, J.H. (1984) Echolocation and foraging behavior in the Hawaiian hoary bat, Lasiurus cinereus. Canadian Journal of Zoology, 62, 2113-2120.

Borror, D.J., Triplehorn, C.A. \& Johnson, N.F. (1989) An introduction to the study of insects, 6th edn. Saunders College Publishing, Philadelphia.

Campbell, E.W. (2002) Dermal toxicity of selected agricultural pesticides, pharmaceutical products, and household chemicals to introduced Eleutherodactylus frogs in Hawaii. Rep. no. QA693. USDA/APHIS/WS/NWRC, Hilo, Hawaii.

Daszak, P., Cunningham, A.A. \& Hyatt, A.D. (2003) Infectious disease and amphibian population declines. Diversity and Distributions, 9, 141-150.

Eldredge, L.G. \& Miller, S.E. (1995) How many species are there in Hawaii? Bishop Museum Occasional Papers, 41, 3-18.

Ellis, S., Kuehler, C., Lacy, R., Hughes, K. \& Seal, U.S. (1992) Hawaiian forest birds conservation assessment and management plan, Captive Breeding Specialist Group. IUCN - the World Conservation Union/Species Survival Commission, Hilo, Hawaii.

Fogarty, J.H. \& Vilella, F.J. (2001) Evaluating methodologies to survey Eleutherodactylus frogs in montane forests of Puerto Rico. Wildlife Society Bulletin, 29, 948-955.

Fogarty, J.H. \& Vilella, F.J. (2002) Population dynamics of Eleutherodactylus coqui in Cordillera forest reserves of Puerto Rico. Journal of Herpetology, 36, 193-201.

Fullington, G. (2001) Another voice for the coqui. Hawaii Island Journal, 1-15 October, 4.

Goergen, E. \& Daehler, C.C. (2001) Reproductive ecology of a native Hawaiian grass (Heteropogon contortus; Poaceae) versus its invasive alien competitor (Pennisetum setaceum; Poaceae). International Journal of Plant Sciences, 162, 317-326.

Gonser, R.A. \& Woolbright, L.L. (1995) Homing behaviour of the Puerto Rican Frog, Eleutherodactylus coqui. Journal of Herpetology, 29, 481-484.

Hobbs, R.J. \& Huenneke, L.F. (1992) Disturbance, diversity, and invasion: implications for conservation. Conservation Biology, 6, 324-337.

Iverson, S.J., Field, C., Bowen, W.D. \& Blanchard, W. (2004) Quantitative fatty acid signature analysis: a new method of estimating predator diets. Ecological Monographs, 74, 211235.

Joglar, R.L. (1998) Los coquíes de Puerto Rico: su historia natural y conservación. Universidad de Puerto Rico, San Juan, Puerto Rico.

Kraus, F. \& Campbell, E.W. (2002) Human-mediated escalation of a formerly eradicable problem: the invasion of Caribbean frogs in the Hawaiian Islands. Biological Invasions, 4, 327-332.
Kraus, F., Campbell, E.W., Allison, A. \& Pratt, T.K. (1998) New frog introductions to Hawaii: current status, likely impacts, and prospects for control. Hawaii Conservation Conference, Honolulu.

Kraus, F., Campbell, E.W., Allison, A. \& Pratt, T. (1999) Eleutherodactylus frog introductions to Hawaii. Herpetological Review, 30, 21-25.

Lavigne, R.J. \& Drewry, G.E., eds. (1970) Feeding behavior of the frogs and lizards in the tropical wet forest: preliminary report. Vol. PRNC-147, pp. 64-73. Puerto Rico Nuclear Center, Rio Piedras, Puerto Rico.

Ostertag, R. \& Verville, J.H. (2002) Fertilization with nitrogen and phosphorus increases abundance of non-native species in Hawaiian montane forests. Plant Ecology, 162, 77-90.

Pimentel, D. (1955) Biology of the Indian mongoose in Puerto Rico. Journal of Mammalogy, 36, 62-68.

Pitt, W.C. \& Sin, H. (2004a) Dermal toxicity of citric acid based pesticides to introduced Eleutherodactylus frogs in Hawaii. Rep. No. QA-992. USDA/APHIS/WS/NWRC, Hilo, Hawaii.

Pitt, W.C. \& Sin, H. (2004b) Field efficacy and invertebrate nontarget hazard assessment of citric acid spray application for control of introduced Eleutherodactylus frogs in Hawaii. Rep. no. QA-1048. USDA/APHIS/WS/NWRC, Hilo, Hawaii.

Pitt, W.C. \& Sin, H. (2004c) Testing citric acid use on plants. Landscape Hawaii, July/August, 12.

Raloff, J. (2003) Hawaii's hated frogs: Tiny invaders raise a big ruckus. Science News, 163, 11.

Reagan, D.P. (1996) The role of amphibians and reptiles in a West Indian rain forest food web. Contributions of West Indian herpetology: a tribute to Albert Schwartz (ed. by R. Powell and R.W. Henderson), Vol. 12, pp. 217-227. Society for the Study of Amphibians and Reptiles, Ithaca, New York.

Reagan, D.P. \& Waide, R.B., eds (1996) The food web of a tropical rain forest. University of Chicago Press, Chicago.

Rodda, G.H. \& Fritts, T.H. (1992) The impact of the introduction of the colubrid snake Boiga irregularis on Guam's lizards. Journal of Herpetology, 26, 166-174.

Samways, M.J., Caldwell, P.M. \& Osborn, R. (1996) Ground-living invertebrate assemblages in native, planted and invasive vegetation in South Africa. Agriculture, Ecosystems, and Environment, 59, 19-32.

Santana, C.E. \& Temple, S.A. (1988) Breeding biology and diet of the red-tailed hawks in Puerto Rico. Biotropica, 20, 151-160.

Savidge, J.A. (1988) Food habits of Boiga irregularis, an introduced predator on Guam. Journal of Herpetology, 22, 275-282.

Schwartz, A. \& Hendersen, R.W. (1991) Amphibians and reptiles of the West Indies: description, distributions, and natural history. University of Florida Press, Gainesville.

Singer, S.R. (2001) Viewpoint: save the 'Hawaiian' coqui! Hawaii Island Journal, 16-20 September, 4-5.

Snyder, N.F.R., Wiley, W.J. \& Kepler, C.B. (1987) The parrots of Luquillo: natural history and conservation of the Puerto Rican parrot. Western Foundation of Vertebrate Zoology, Los Angeles, CA.

Stattersfield, A.J., Crosby, M.J., Long, A.J. \& Wege, D.C. (1998) Endemic bird areas of the world: priorities for biodiversity conservation. BirdLife International, Cambridge. 
Stewart, M.M. (1995) Climate driven population fluctuations in rain forest frogs. Journal of Herpetology, 29, 437-446.

Stewart, M.M. \& Pough, F.H. (1983) Population density of tropical forest frogs: relation to retreat sites. Nature, 221, $570-572$.

Stewart, M.M. \& Woolbright, L.L. (1996) Amphibians. The food web of a tropical rain forest (ed. by D.P. Reagan and R.B. Waide), pp. 363-398. University of Chicago Press, Chicago.

Tilman, D. (1987) Secondary succession and the pattern of plant dominance along experimental nitrogen gradients. Ecology, 74, 2179-2191.

Townsend, D.S. \& Stewart, M.M. (1985) Direct development in Eleutherodactylus coqui (Anura: Leptodactylidae): a staging table. Copeia, 1985, 423-436.

Townsend, D.S. \& Stewart, M.M. (1986) Courtship and mating behavior of a Puerto Rican frog, Eleutherodactylus coqui. Herpetologica, 42, 165-170.

Townsend, D.S. \& Stewart, M.M. (1994) Reproductive ecology of the Puerto Rican Frog Eleutherodactylus coqui. Journal of Herpetology, 28, 34-40.

Townsend, D.S., Stewart, M.M. \& Pough, F.H. (1984) Male parental care and its adaptive significance in a Neotropical frog. Animal Behavior, 32, 421-431.

van Riper, C. III \& van Riper, S.G. (1985) A summary of known parasites and diseases recorded from the avifauna of the Hawaiian Islands. Hawaii's terrestrial ecosystems: preservation and management (ed. by C.P. Stone and J.M. Scott), pp. 298371. Cooperative National Park Resources Studies Unit, University of Hawaii, Honolulu.

Vilella, F.J. (1998) Biology of the mongoose (Herpestes javanicus) in a rain forest in Puerto Rico. Biotropica, 30, 120-125.

Vitousek, P.M. (1986) Biological invasions and ecosystem properties: can species make a difference? Ecology of biological invasions of North America and Hawaii (ed. by H.A. Mooney), pp. 163-176. Springer-Verlag, New York.

Waide, R.B. (1996) Birds. The food web of a tropical rain forest (ed. by D.P. Reagan and R.B. Waide), pp. 363-398. University of Chicago Press, Chicago.

Whitaker, J.O. \& Tomich, P.Q. (1983) Food habits of the hoary bat, Lasiurus cinereus, from Hawaii. Journal of Mammalogy, 64, $150-151$.

White, G.C. \& Burnham, K.P. (1999) Program MARK: Survival estimation from populations of marked animals. Bird Survey 46 Supplement, 120-138.

Willig, M.R. (1996) Mammals. The food web of a tropical rain forest (ed. by D.P. Reagan and R.B. Waide), pp. 399-431. University of Chicago Press, Chicago.

Woolbright, L.L. (1991) The impact of hurricane Hugo on forest frogs in Puerto Rico. Biotropica, 23, 462-467.

Woolbright, L.L. \& Stewart, M.M. (1987) Foraging success of the tropical frog, Eleutherodactylus coqui: the cost of calling. Copeia, 1987, 69-75. 